\title{
Mahasweta Devi's Draupadi: Resonances of Patriarchy, Crime and Confrontation
}

\author{
Shubhpreet Sandhu \\ PGGC, Sec 11 \\ Chandigarh, India \\ dharamsandhu@gmail.com
}

\begin{abstract}
The present paper aims to capture the position of a woman in male dominated culture and how she is owned as property in Mahasweta Devi's short story "Draupadi". In this story she raises her voice against the Indian feudalism and talks about the ingratitude of government. There are three stories in Breast stories translated by Gayatri Chakravarty Spivak named "Draupadi", "Breast Giver" And "Behind the Bodice." All these stories have a theme of exploitation and patriarchy. In Draupadi, Devi speaks about the violence faced by its protagonist Dopdi Mejhen.
\end{abstract}

Keywords: Patriarchy. Exploitation, Marginalization.

Mahasweta Devi is one of the well-known Indian feminist writers. She has embellished feminist writings over a long period of time. She wrote basically for the rights and empowerment of the tribal people of Bengal. As a social activist, she has always worked for the upliftment of downtrodden class and almost all her protagonists fight against exploitation especially sexual violence and abuse. Devi raised her voice against the upper class corruption and injustice. She portrayed the Indian patriarchy system in her writings. In the introduction to Agnigarbha Devi wrote, "Life is not mathematics and humanbeings are 
not made for the sake of politics. I want to change in the Present social system and do not believe in mere party politics. "(4)

Devi's writing style is very startling. She uses a number of techniques for etching her characters onto literary landscapes. Malini Bhattacharya says, "there are few writers of her stature today in whose career creative writing and activism have been so closely intertwined." (EPW, 10 May 1997-1003). She presents the shocking realities of social economics and politics that happen behind the curtain. There are three tales entitled in Breast Stories translated by Gayatri Chakravarty Spivak named Draupadi, Breast Giver (Stanadayini) and Behind the Bodice (Choli ke Pichhe). All these stories have a theme of exploitation and patriarchy. Twenty seven years old tribal Dopdi who is struggling for her survival for food and for water was "Mosnotorious female, long wanted in many.. (P395 Draupadi). She is from a Santhal tribe and is trying to escape from the special forces after murdering Surja Sahu and his son, occupying upper-caste wells and tube wells during the drought".P395 Army troops have been assigned in the forest of Jharkhani to suppress the rebellion of tribal people against the feudalism and caste systems.

From ages, women have always been the victims of exploitation, humiliation and are seen as a sexual object. When Dopdi Mejhen is apprehended, she is treated only as a mere body. The process of commodification has been started when she is being captured by the policemen."Mr. Senanayak, the elderly Bengali specialist in combat and extreme-Left politics,"(P.393) before going to dinner gives orders and says, "Make her do the needful,". After that Dopdi is raped by a group of policemen "Shaming her, a tear trickles out of the corner of her eye...sees her breasts...are bitten raw, the nipples torn .How many? Four-fivesix-seven then Draupadi has passed out'(P.401).

She was gang raped by the authorities so that she would name her comrades. Though she is shamed to the core and treated as an object, she still possesses an indomitable spirit. 
Wilson points out, "Refusing to cover herself, she uses her ravaged body as a weapon by which to censure the man who has sanctioned the gang rape as a weapon against her. (144).

Mahasweta Devi's Dopdi is a recreation of Draupadi of the epic, Mahabharata in which there is one villain who dares to pull her saree to confiscate her modesty whereas Devi's Dopdi has to face so many villains. Devi presents a contrast. Mythological character Drapaudi is saved by the incarnation of Krishna whereas tribal Dopdi is tortured and subjugated by the patriarchy. But tribal Dopdi is presented as a very strong and a powerful character. In Spite of so much oppression, she remains determined and firm. "For the first time Senanayak is afraid to stand before an unarmed target, terribly afraid." (p402). This statement highlights that at the end, dominated male has to feel inferior before a female. The voice of Dopdi weakens the voices of a male power structure. Since ages, the man in power always tries to exploit and oppress the inferior one. Same thing does happen in Devi in works. Women in Indian society are brutally exploited by the men in power. After the capture of Dopdi, "she feels her arms and legs still tied to four posts, something sticky under her arms and waist. Only the gag has been removed.'(p401).

In the conclusion, Devi is able to capture the transition of the marginalized Dopdi from an abused state to angry rebels. When the guard offers her water she "pours the water down on the ground. Tears flow down her piece of cloth with her teeth...Senanayak walks out surprised and sees Draupadi naked, walking towards him in the bright sunlight with her head high". She became so fearless and "stands before him, naked. Thigh and pubic hair matted with dry blood. Two breasts, two wounds."(p402).

Unlike other passive rape victims, Dopdi does not suffer in silence. With unbeatable spirit marginalized Dopdi faces her rapist with resistant and firm spirit. Devi presents Dopdi as a very vigorous character who takes stand against the injustice done by the upper class men. Conquering her pain and oppression, she emerges as a most powerful "subject". Devi 
exposes the patriarchal society where Dopdi became a symbol of millions of tribal women who are oppressed, marginalized and humiliated by the agents of politics. She challenges the authorities to behold the atrocity committed by them and states "what's the use of clothes? You can strip me but how can you clothe me again? Are you a man?. There isn't a man here that I should be ashamed."(P402).

This short story reverberates the bitter, powerful and shocking realities of present time which is based on the lofty patriarchal traditions of Indian culture, Devi shows what actually happens to a woman when they are seen as merely 'target objects'. Dopdi displays her mutilated body to Senanayak as "the object of your search". The words of Rajeshwari Sunder Rajan in the story of Draupadi's Disrobing are: "Sexual molestation of any form happens to be Patriarchy's method of social control rather than pathology of sexual violence as such." (p102).Thus it can be said that Devi's writing does not only record the oppression faced by tribal people but also mirrors the resistance to it. 
Works Cited:-

"Writing and sexual difference." Critical Inquiry Winter 1981.Vol 8 .No 2, 1981 pp,381-402 Agnigarbha,:Radha Krishna Parkashan Press, New Delhi, 1979 . Print

Bhattacharya, Malini "MahashwetaDevi : Activist and Writer", EPW (10,May 1997) 1093.

Wenzel, Jennifer. "Epic Struggles over India's Forests in Mahasweta Devi’s Short Fiction.” Journal of Comparative Poetics 18 (1998): 127-158. JSTOR. Web. 2 May 2015. 